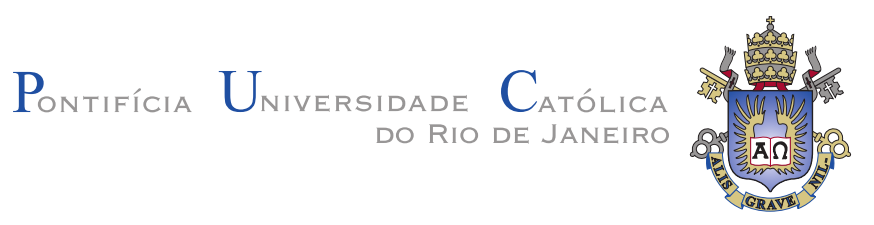

Luiz Felipe Nobili França

\title{
Topological Properties of Partially Hyperbolic
} Attractors

Tese de Doutorado

Thesis presented to the Programa de Pós-graduação em Matemática of the Departamento de Matemática da PUC-Rio, as partial fulfillment of the requirements for the degree of Doutor em Matemática.

Advisor : Prof. Lorenzo J. Díaz Co-Advisor: Prof. Flavio Abdenur 
Pontifícia Universidade Católica $_{\text {a }}$

DO RIO DE JANEIRO

Luiz Felipe Nobili França

Topological Properties of Partially Hyperbolic

Attractors

Thesis presented to the Programa de Pós-Graduação em Matemática of the Departamento de Matemática do Centro Técnico Científico da PUC-Rio, as partial fulfillment of the requirements for the degree of Doutor.

Prof. Lorenzo J. Díaz Advisor Departamento de Matemática - PUC-Rio

Prof. Flávio Erthal Abdenur Co-Advisor Ventor Investimentos

Prof. Jairo da Silva Bochi Departamento de Matemática - PUC-Rio

Prof. Rafael Oswaldo Ruggiero Rodriguez

Departamento de Matemática - PUC-Rio

Prof. Alexander Eduardo Arbieto Mendoza

Instituto de Matemática - UFRJ

Prof. Carlos Gustavo Tamm de Araújo Moreira Instituto Nacional de Matemática Pura e Aplicada- IMPA

Prof. Paul Alexander Schweitzer, S.J.

Departamento de Matemática-PUC-Rio

Profa. Isabel Lugão Rios Instituto de Matemática - UFF

José Eugenio Leal Coordinator of the Centro Técnico Científico da PUC-Rio 
All rights reserved. It is forbidden partial or complete reproduction without previous authorization of the university, the author and the advisor.

\section{Luiz Felipe Nobili França}

Studied at UERJ for his undergraduate degree, and at PUCRio for his Master and Doctoral degrees.

Bibliographic data Nobili, F

Topological Properties of Partially Hyperbolic Attractors / Luiz Felipe Nobili França; advisor: Lorenzo J. Díaz; coadvisor:Flavio Abdenur . - 2012.

$67 \mathrm{f}$. : il. ; $30 \mathrm{~cm}$

1. Tese (Doutorado em Matemática) - Pontifícia Universidade Católica do Rio de Janeiro, Rio de Janeiro, 2012.

Inclui bibliografia

1. Matemática - Teses. 2. atrator. 3. folheação. 4. minimalidade. 5. transitividade. 6. decomposição espectral. 7. interior não vazio. I. Díaz, L. J.. II. Pontifícia Universidade Católica do Rio de Janeiro. Departamento de Matemática. III. Título. 


\section{Acknowledgments}

My acknowledgements to...

Flavio Abdenur, for advising me in my master and most part of my doctoral program. I'm very grateful for the encouragement and enthusiasm he passed me, and for suggesting the interesting problem that originate this thesis.

Lorenzo Díaz for kindly accept advising me in the last year of my doctoral program. His commitment, dedication and peculiar care in rigor are some of his attributes. His assistance was of inestimable value. I surely learnt a lot from him.

The others Professors and staff of the department, for kindly help in every day stuff.

CNPq and FAPERJ for the financial support, without which this work could not be accomplished.

My family, for always believing and encouraging me in every step of this journey. In special, to my beloved wife Edilaine with whom my life and dreams are shared.

All my friends from PUC for the memorable times we share together. They surely made the working ambient so much nicer and comfortable. To my friends from the others institutions as UFRJ, UFF and IMPA. 


\section{Abstract}

Nobili, F; Díaz, L. J.; . Topological Properties of Partially Hyperbolic Attractors. Rio de Janeiro, 2012. 67p. Tese de Doutorado - Departamento de Matemática, Pontifícia Universidade Católica do Rio de Janeiro.

In this work we extend the results in (12) and (22) about the minimality of one of the strong foliations (stable or unstable), for the case of robustly transitive attractors that is partially hyperbolic with one dimensional center bundle. In our context the partial hyperbolicity is defined only in the attractor. Some consequences are obtained as the verification that these attractors are (robustly) homoclinic classes, have (robustly) empty interior and admit a spectral decomposition. Similar results still holds in the case of generically transitive attractors.

\section{Keywords}

attractor. foliation. minimality. transitivity. spectral decomposition. non-empty interior. 


\section{Resumo}

Nobili, F; Díaz, L. J.; . Propriedades Topológicas de Atratores Parcialmente Hiperbólicos. Rio de Janeiro, 2012. 67p. Tese de Doutorado - Departamento de Matemática, Pontifícia Universidade Católica do Rio de Janeiro.

Neste trabalho estendemos os resultados em (12) e (22), sobre a minimalidade de uma das folheações (estável ou instável forte), para o caso de atratores robustamente transitivos parcialmente hiperbólico e com direção central unidimensional. No nosso contexto a hiperbolicidade parcial esta definida somente no atrator. Algumas consequências são obtidas tais como a verificação de que estes atratores são (robustamente) classes homoclínicas, possuem (robustamente) interior vazio e admitem uma decomposição espectral. Resultados similares ainda valem no caso de atratores genericamente transitivos.

\section{Palavras-chave}

atrator. folheação. minimalidade. transitividade. decomposição espectral. interior não vazio. 


\section{Contents}

1 Introduction $\quad 9$

2 Preliminaries $\quad 15$

$\begin{array}{lll}3 & \text { Invariant foliations (for sets) } & 17\end{array}$

$4 C^{1}$-Generic setting $\quad 23$

$4.1 C^{1}$-Generic homoclinic classes $\quad 23$

4.2 $C^{1}$-Generic transitive sets $\quad 24$

4.3 An extention of the partially hyperbolic splitting. 27

$\begin{array}{ll}4.4 & \text { Lebesgue measure and genericity } \\ 29\end{array}$

5 Minimality $\quad 31$

5.1 General properties of $u$ and $s$-minimal sets 31

5.2 Pertubations of isolated $u$ and $s$-minimal sets 34

5.3 A criterium for minimality 37

$5.4 s$-Minimal attractors $\quad 42$

6 A dichotomy about $(s, 1, u)$-partially hyperbolic attractors $\quad 45$

6.1 Central Curves: Classification of Periodic Points 46

6.2 Proof of Theorem 6.1

$\begin{array}{lll}7 & \text { Spectral decomposition } & 57\end{array}$

8 Final Considerations $\quad 62$ 
Whatever you can do or dream, begin it.

Goethe. 